UDC: $579.846 .2: 22$

\author{
I.V. Kushkevych ${ }^{1}$, H.L. Antonyak ${ }^{2}$, R.V. Fafula ${ }^{3}$ \\ ${ }^{1}$ Institute of Animal Biology of NAAS of Ukraine, V.Stus St 38, Lviv 79034, Ukraine \\ ${ }^{2}$ Ivan Franko National University of Lviv, Hrushevsky St. 4, 79005, Lviv, Ukraine \\ ${ }^{3}$ Danylo Halytsky Lviv National Medical University, Pekarska St 69, Lviv 79010, Ukraine \\ e-mail: ivan.kushkevych@gmail.com
}

\title{
ACTIVITY AND KINETIC PROPERTIES OF SUPEROXIDE DISMUTASE OF THE SULFATE-REDUCING BACTERIA DESULFOVIBRIO PIGER VIB-7 AND DESULFOMICROBIUM SP. ROD-9
}

\begin{abstract}
The aim of our work was to study superoxide dismutase activity of cell-free extracts of Desulfovibrio piger Vib-7 and Desulfomicrobium sp. Rod-9 isolated from the human large intestine and to carry out the analysis of the enzyme reaction kinetic properties. Methods. Microbiological, biochemical, biophysical methods, and methods of statistical processing of the results were used. Results. Specific activity of superoxide dismutase from the sulfate-reducing bacteria was studied. The influence of different temperature, $\mathrm{pH}$ and substrate concentration on the activity of studied enzymes was showed. The analysis of the kinetic properties of the superoxide dismutase in the bacterial strains, based on experimental data, was carried out. The initial (instantaneous) reaction rate $\left(V_{0}\right)$, maximum rate of the enzyme reaction $\left(V_{\text {max }}\right)$, and Michaelis constants $\left(K_{m}\right)$ of the superoxide dismutase reaction for both strains was calculated. Conclusion. The kinetic parameters of superoxide dismutase reaction in both bacterial strains were not statistically different. The obtained data on optimum of pH (7.5-9.5) on the activity of the enzyme were consistent to the environment conditions of the human large intestine. These conditions can provide the intensive growth of the bacterial strains, process of the dissimilatory sulfate reduction and, thus, the accumulation of hydrogen sulfide in the gut.
\end{abstract}

Key words: sulfate-reducing bacteria, superoxide dismutase activity, kinetic properties.

Superoxide dismutase is considered to be an important enzyme in protection of aerobes against oxidant damage, and increased tolerance to oxidant stress is associated with induction of this enzyme. The superoxide dismutase eliminates $\mathrm{O}_{2}^{-}$ by dismutation to $\mathrm{H}_{2} \mathrm{O}_{2}$ and $\mathrm{O}_{2}$. The presence of superoxide dismutase activity in anaerobic bacteria has been demonstrated for the first time in $D$. desulfuricans and Desulfotomaculum nigrificans $[4,5]$. The studied sulfate-reducing bacteria carry out dissimilatory sulfate reduction to hydrogen sulfide [13]. These bacteria are strictly anaerobic microorganisms and they are present in anoxic environments with high sulfate concentrations [12]. The aerobic conditions inhibit dissimilatory sulfate reduction in the most of the sulfate-reducing bacteria [2]. They can grow using sulfate 
only in the absence of molecular oxygen. Such anaerobic conditions are available in the intestine of humans and animals [12].

In the previous researches it has been shown that studied Desulfovibrio piger Vib-7 and Desulfomicrobium sp. Rod-9 strains can accumulate hydrogen sulfide and acetate in the human intestine. These compounds are cytotoxic and carcinogenic to intestinal cells, they can cause inhibition of cytochrome oxidase, oxidation processes butyrate by colonocytes, destruction of epithelial cells, develop ulcers, inflammation with subsequent development of colon cancer $[2,12]$. In view of the facts, it is interesting to study one of the antioxidant systems of the isolated anaerobic bacterial strains. The data about superoxide dismutase activity and the kinetic properties of the enzyme of sulfate-reducing bacteria Desulfovibrio piger Vib-7 and Desulfomicrobium sp. Rod-9 isolated from the human large intestine have never been well-characterized and has not been studied yet.

The aim of our work was to study superoxide dismutase activity of cell-free extracts of the sulfate-reducing bacteria Desulfovibrio piger Vib-7 and Desulfomicrobium sp. Rod-9 isolated from the human large intestine and to carry out the analysis of the kinetic properties of the enzyme reaction.

\section{Materials and methods}

The objects of the study were the strains of the sulfate-reducing bacteria $D e$ sulfovibrio piger Vib-7 and Desulfomicrobium sp. Rod-9 isolated from the human large intestine $[13,14]$.

Bacterial growth and cultivation. The bacteria were grown in nutrition modified Kravtsov-Sorokin's liquid medium [13]. The sterile $10 \mathrm{~N}$ solution of $\mathrm{NaOH}$ $(0.9 \mathrm{ml} / \mathrm{l})$ was used to provide the final $\mathrm{pH} 7.2$ in the medium. The medium was heated in boiling water for $30 \mathrm{~min}$ in order to obtain an oxygen-free system, and cooled to $+30^{\circ} \mathrm{C}$ temperature. The bacteria were grown for 72 hours at $+37^{\circ} \mathrm{C}$ under anaerobic conditions. The tubes were brim-filled with medium and closed to provide anaerobic conditions.

Obtaining cell-free extracts. The cells were collected at the beginning of the stationary phase, suspended at $+4{ }^{\circ} \mathrm{C}$ in buffer containing $50 \mathrm{mM}$ potassium phosphate buffer ( $\mathrm{pH} 7.5$ ) and $10^{-5} \mathrm{M}$ EDTA (ethylenediaminetetraacetic acid) to bind heavy metal ions. $10^{-5} \mathrm{M}$ PMSF (phenylmethylsulfonyl fluoride), functioning at a $\mathrm{pH}$ higher 7.0, was added for inhibition of proteases. After that, a suspension of cells $(50-100 \mathrm{mg} / \mathrm{ml})$ was obtained. The cells were homogenized using the ultrasonic disintegrator at $22 \mathrm{kHz}$ for 5 minutes at $0{ }^{\circ} \mathrm{C}$ to obtain the cell-free extracts. The extracts were centrifuged at $+4{ }^{\circ} \mathrm{C}$ for $10 \mathrm{~min}$ at $15,000 \times \mathrm{g}$; the pellet was then used as sedimentary fraction, and the supernatant obtained was termed the soluble fraction. This extract was subjected to further centrifugation at $180,000 \times \mathrm{g}$ for $1 \mathrm{~h}$ to totally eliminate the membrane fraction. A clear supernatant, containing the soluble fraction, was then used as the cell-free extract. Protein concentration in the cell-free extracts was determined by the Lowry method [15].

Measuring superoxide dismutase activity. The activity of superoxide dismutase is determined based on inhibition of nitroblue tetrazolium (NBT) reduction in the 
presence of NADH and phenazine methosulfate (PMS). The incubation mixture contained $1 \mu$ EDTA $\left(10^{-5} \mathrm{M}\right), 1 \mathrm{mg}$ of gelatin ( $10 \%$ solution $), 0.3 \mathrm{ml} \mathrm{NBT}(0.407 \mathrm{mM})$, $0.1 \mathrm{ml}$ PMS $(1.8 \mu \mathrm{M}), 0.1 \mathrm{ml}$ of $1 \mathrm{mM}$ NADH. The supernatant was added to the incubation mixture in a volume of $0.1 \mathrm{ml}$ that causes the inhibition NBT reduction. The total volume of the incubation mixture to general $3 \mathrm{ml}$ was adjusted by 0.15 $\mathrm{M}$ phosphate buffer ( $\mathrm{pH}$ 7.8). The control samples contained the same components except the supernatant, there was added the same amount of buffer in the tube. The launch of the reaction occurs by adding $0.1 \mathrm{ml}$ of NADH $(1 \mathrm{mM})$ in the experimental and control samples. The incubation was carried out for $10 \mathrm{~min}$ in the darkness at room temperature. Optical density of experimental and control samples was determined on a spectrophotometer (Biospectrophotometer, Eppendorf, USA) at a wavelength of $540 \mathrm{~nm}$ [3].

Kinetic analysis. The study of the kinetic properties of the enzyme reaction was carried out in a standard incubation medium, modified by physical and chemical characteristics or the relevant components (the incubation time, substrate concentration, temperature and $\mathrm{pH}$ ). The kinetic parameters characterizing the product accumulation (NADH-phenazine methosulfate nitroblue tetrazolium formazan) are initial (instantaneous) reaction rate $\left(\mathrm{V}_{0}\right)$, maximum rate of the reaction $\left(\mathrm{V}_{\max }\right)$, maximum amount of the reaction product $\left(\mathrm{P}_{\max }\right)$ and characteristic reaction time (time half saturation, $\tau$ ) was determined. The kinetic parameters characterizing superoxide dismutase reactions are Michaelis constant $\left(\mathrm{K}_{\mathrm{m}}\right)$ and maximum reaction rate of product formation were determined by Lineweaver-Burk plot [10]. The dependence of the rate of product formation on the substrate concentration was constructed in the coordinates $\{1 / \mathrm{V}$ on $1 / \mathrm{S}\}$, where $\mathrm{S}$ is the concentration of the substrate, and $\mathrm{V}$ is the rate of product formation at a substrate concentration.

Statistical analysis. Kinetic and statistical calculations of the results were carried out using the MS Office software and OriginPro 8.0 computer programs. The research results were treated by the methods of variation statistics using Student $t$-test. The equation of the straight line that the best approximates the experimental data was calculated by the method of the least squares. The absolute value of the correlation coefficient $r$ was from 0.90 to 0.99 . The statistical significance of the parameters was tested by the Fisher's $F$-test. The accurate approximation was when $\mathrm{P} \leq 0.05$ [1].

\section{Results and Discussion}

The activity of superoxide dismutase in the different fractions including cell-free extract, soluble, and sedimentary was studied (Table 1). Our results have demonstrated that the highest level of the enzyme activity was in cell-free extracts $(1326.43 \pm$ 142.76 and $1120.72 \pm 88.56 \mathrm{U} \times \mathrm{mg}^{-1}$ protein for D. piger Vib-7 and Desulfomicrobium sp. Rod-9, respectively). Considerably less activity was measured in the soluble fraction compared to the cell-free extracts. The lowest superoxide dismutase activity was found in sedimentary fraction, it the values equal to $125.27 \pm 15.13$ and $99.55 \pm 8.92 \mathrm{U} \times \mathrm{mg}^{-1}$ protein. 
Table 1

Superoxide dismutase activity in the different fractions prepared from Desulfovibrio piger Vib-7 and Desulfomicrobium sp. Rod-9 cells

\begin{tabular}{|l|c|c|}
\hline \multirow{2}{*}{\multicolumn{2}{|c|}{ Fractions }} & \multicolumn{2}{c|}{ Superoxide dismutase activity (U $\times$ mg $^{-1}$ protein) } \\
\cline { 2 - 3 } & Desulfovibrio piger Vib-7 & Desulfomicrobium sp. Rod-9 \\
\hline Cell-free extract & $1326.43 \pm 142.76$ & $1120.72 \pm 88.56$ \\
\hline Individual fractions: & $889.76 \pm 77.12$ & $741.62 \pm 67.69$ \\
\hline soluble & $125.27 \pm 15.13$ & $99.55 \pm 8.92$ \\
\hline sedimentary &
\end{tabular}

Comment: Enzyme activity is determined at ten-minute incubation.

From the literature data it is known that the activity of all enzymes depends on temperature and $\mathrm{pH}[4,5]$. That's why, the next our task was to determine the activity of the studied enzyme in the cell-free extracts under the influence of temperature and $\mathrm{pH}$ (Fig. 1). The maximum superoxide dismutase activity for both bacterial strains was determined at $+30{ }^{\circ} \mathrm{C}$ temperature. An increase or decrease in the temperature of incubation led to a decrease of the enzyme activity in the cell-free bacterial extracts.
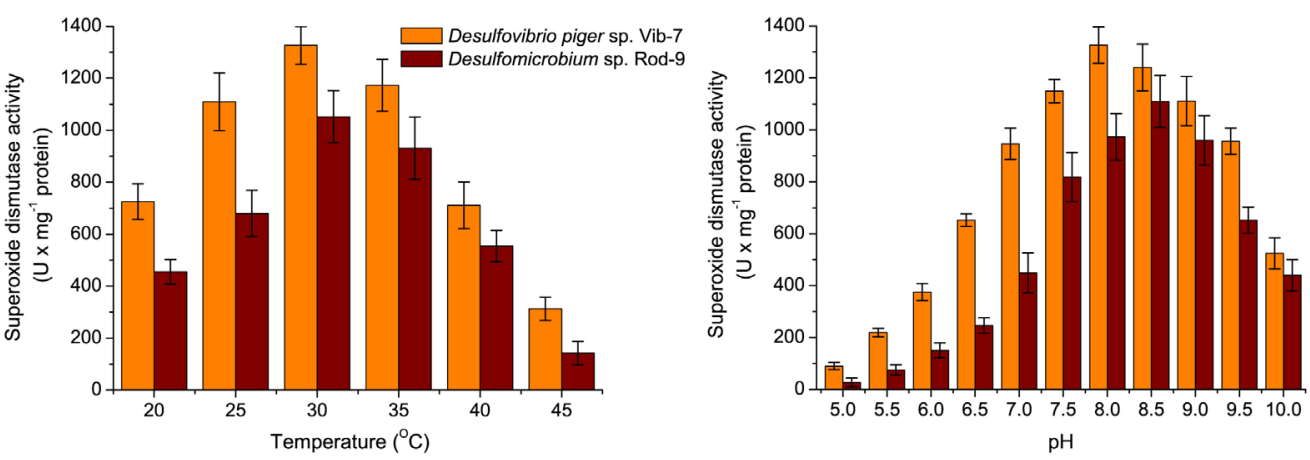

Fig. 1. Effect of temperature and $\mathrm{pH}$ on superoxide dismutase activity in cell-free extracts of Desulfovibrio piger Vib-7 and Desulfomicrobium sp. Rod-9.

The intestinal sulfate-reducing bacteria can grow, dissimilating sulfate, in the human gut at $\mathrm{pH}$ 8.0...9.0. The influence of this factor on superoxide dismutase activity of intestinal sulfate-reducing bacteria has not been studied yet. The $\mathrm{pH}$ values were slightly expanded and the superoxide dismutase activity was determined over a wide $\mathrm{pH}$ range from 5 to 10 . The enzyme activity was maximum under $\mathrm{pH}$ range from 7.5-9.5. The highest activity was measured in the cell-free extracts of $D$. piger Vib-7 at pH 8.0 and Desulfomicrobium sp. Rod-9 at pH 8.5.

To study the characteristics and mechanism of superoxide dismutase reaction, the initial (instantaneous) reaction rate $\left(\mathrm{V}_{0}\right)$, maximum rate of the reaction $\left(\mathrm{V}_{\max }\right)$, 
maximum amount of reaction product $\left(\mathrm{P}_{\max }\right)$ and reaction time $(\tau)$ were defined. The dynamic of the product formation in the cell-free extracts to study the kinetic superoxide dismutase reaction was investigated (Fig. 2).

Our experimental data showed that the kinetic curves of superoxide dismutase reaction have tendency to saturation (Fig. $2 A$ ). Analysis of the results allows to reach the conclusion that the kinetics of superoxide dismutase activity in cell-free extracts of the studied bacteria was consistent to the zero-order reaction in the range of 0-60 $\sec$ (the graph of the dependence of product on the incubation time was almost linear in this interval of time). Therefore the duration of the incubation of bacterial cells extracts was $60 \mathrm{sec}$ in subsequent experiments.

The amount of product in the superoxide dismutase reaction from $D$. piger Vib7 was higher compared to Desulfomicrobium sp. Rod-9 in the entire range of time factor. The basic kinetic properties of superoxide dismutase reaction in the cell-free extracts of the sulfate-reducing bacteria were calculated by linearization of the data in $\{\mathrm{P} / \mathrm{t} ; \mathrm{P}\}$ coordinates (Fig. $2 B$, Table 2).
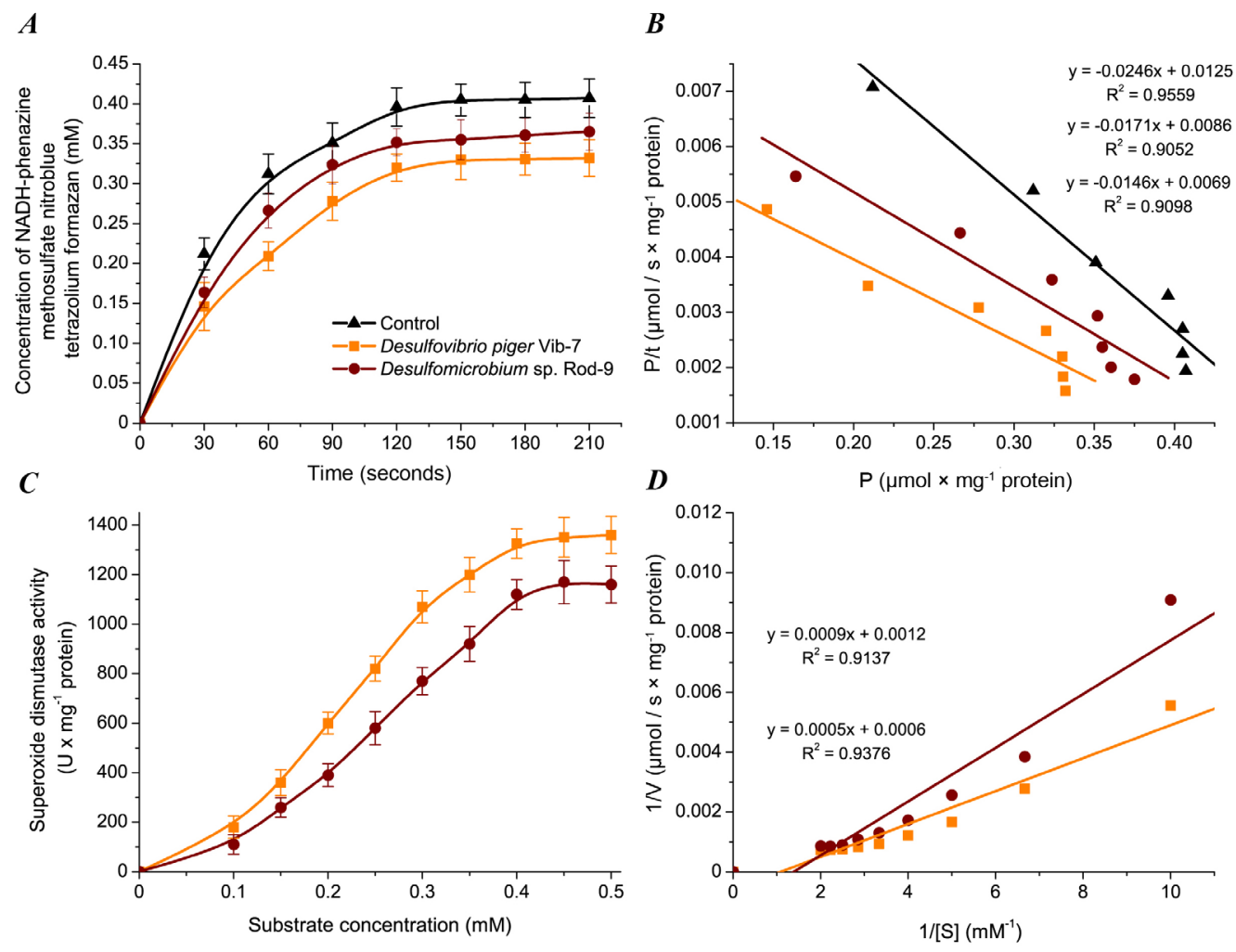

Fig. 2. Kinetic parameters of the superoxide dismutase activity in cell-free extracts

A - dynamics of product accumulation $(\mathrm{M} \pm \mathrm{m}, \mathrm{n}=3)$; $\mathrm{B}$ - linearization of the curves of the product formation in $\{\mathrm{P} / \mathrm{t} ; \mathrm{P}\}$ coordinates $\left(\mathrm{n}=3 ; \mathrm{R}^{2}>0.9 ; \mathrm{F}<0.02\right) ; \mathrm{C}$ - the effect of substrate concentration on superoxide dismutase activity $(\mathrm{M} \pm \mathrm{m}, \mathrm{n}=3)$; $\mathrm{D}$ - linearization of concentration curves, shown in fig. $2 \mathrm{C}$, in the Lineweaver-Burk plot, where $\mathrm{V}$ is the rate of superoxide dismutase reaction and $\mathrm{S}$ is substrate concentration $\left(\mathrm{n}=3 ; \mathrm{R}^{2}>0.95 ; \mathrm{F}<0.005\right)$. 
The kinetic parameters of superoxide dismutase reaction in cell-free extracts of D. piger Vib-7 and Desulfomicrobium sp. Rod-9 were not statistically different. The values of initial (instantaneous) rate $\left(\mathrm{V}_{0}\right)$ for superoxide dismutase reaction in both bacterial strains were calculated by the maximal amount of the product reaction $\left(\mathrm{P}_{\max }\right)$. As shown in Table 2, $\mathrm{V}_{0}$ for superoxide dismutase was higher in the cell-free extracts of $D$. piger Vib-7 $\left(0.0086 \pm 0.00073 \mu \mathrm{mol} / \mathrm{s} \times \mathrm{mg}^{-1}\right.$ protein $)$ compared to Desulfomicrobium sp. Rod-9 (0.0069 $\pm 0.00055 \mu \mathrm{mol} / \mathrm{s} \times \mathrm{mg}^{-1}$ protein). Based on these data, we suppose that the $D$. piger Vib-7 bacterial cells can be more resistant to molecular oxygen effect compared to Desulfomicrobium sp. Rod-9 cells.

Table 2

Kinetic parameters of the product formation in cell-free extracts of Desulfovibrio piger Vib-7 and Desulfomicrobium sp. Rod-9

\begin{tabular}{|l|c|c|}
\hline \multirow{2}{*}{ Kinetic parameters } & \multicolumn{2}{|c|}{ Sulfate-reducing bacteria } \\
\cline { 2 - 3 } & Desulfovibrio piger Vib-7 & Desulfomicrobium sp. Rod-9 \\
\hline $\mathrm{V}_{0}\left(\mu \mathrm{mol} / \mathrm{s} \times \mathrm{mg}^{-1}\right.$ protein $)$ & $0.0086 \pm 0.00073$ & $0.0069 \pm 0.00055$ \\
\hline $\mathrm{P}_{\max }\left(\mu \mathrm{mol} \times \mathrm{mg}^{-1}\right.$ protein $)$ & $0.503 \pm 0.045$ & $0.473 \pm 0.037$ \\
\hline$\tau$ (seconds $)$ & $58.579 \pm 5.22$ & $69.493 \pm 7.12$ \\
\hline
\end{tabular}

Comment: $\mathrm{V}_{0}$ is initial (instantaneous) reaction rate; $\mathrm{P}_{\max }$ is maximum amount (plateau) of the product of reaction; $\tau$ is the reaction time (half saturation period). Statistical significance of the values $\mathrm{M} \pm \mathrm{m}, \mathrm{n}=3$.

The kinetic analysis of superoxide dismutase reaction depending on the substrate concentration was carried out. According to the obtained results, the product formation increasing in the concentrations range from 0.1 until $0.5 \mathrm{mM}$ provided a monotonic increase of studied enzyme activity and its output to the plateau (Fig. 2C). Curves of the dependence $\{1 / \mathrm{V} ; 1 /[\mathrm{S}]\}$ were different by tangent slope and intersect the vertical axis in one point (Fig. 2D). The basic kinetic parameters of superoxide dismutase reaction in cell-free extracts of $D$. piger Vib-7 and Desulfomicrobium sp. Rod-9 was identified by linearization of the data in the Lineweaver-Burk plot (Table 3).

Table 3

Kinetic parameters of the product formation in the cell extracts depending on substrate concentration in the incubation medium

\begin{tabular}{|l|l|l|}
\hline \multirow{2}{*}{ Kinetic parameters } & \multicolumn{2}{|c|}{ Sulfate-reducing bacteria } \\
\cline { 2 - 3 } & \multicolumn{1}{|c|}{ Desulfovibrio piger Vib-7 } & \multicolumn{1}{c|}{ Desulfomicrobium sp. Rod-9 } \\
\hline $\mathrm{V}_{\max }\left(\mu \mathrm{mol} / \mathrm{s} \times \mathrm{mg}^{-1}\right.$ protein $)$ & $1666.67 \pm 174.92$ & $833.33 \pm 88.54 * *$ \\
\hline $\mathrm{K}_{\mathrm{m}}(\mathrm{mM})$ & $0.833 \pm 0.071$ & $0.750 \pm 0.068$ \\
\hline
\end{tabular}

Comment: $\mathrm{V}_{\max }$ is maximum rate of the enzyme reaction; $\mathrm{K}_{\mathrm{m}}$ is Michaelis constant which was determined by substrate. Statistical significance of the values $\mathrm{M} \pm \mathrm{m}, \mathrm{n}=3$; $* * \mathrm{P}<0.01$, compared to the Desulfovibrio piger Vib-7 strain. 
The $\mathrm{K}_{\mathrm{m}}$ values are in millimolar concentration range which is consistent with similar constants from the literature data [8]. Calculation of the kinetic parameters of superoxide dismutase reaction indicates that the maximum rate $\left(\mathrm{V}_{\max }\right)$ of the product formation in the cell-free extracts of D. piger Vib-7 and Desulfomicrobium sp. Rod9 was statistically different $(P<0.01)$. However, the Michaelis constants $\left(\mathrm{K}_{\mathrm{m}}\right)$ of superoxide dismutase reaction in the cell-free extracts of both bacterial strains were close to each other: $0.833 \pm 0.071$ and $0.750 \pm 0.068 \mathrm{mM}$ for $D$. piger Vib-7 and Desulfomicrobium sp. Rod-9, respectively. The $\mathrm{K}_{\mathrm{m}}$ was slightly different in values while $\mathrm{V}_{\max }$ was significantly different (in 2.0 times) for the both bacterial strains.

Thus, based on the obtained studies results and according to the kinetic parameters of the superoxide dismutase reaction determined for both bacterial strains, we concluded that the $D$. piger Vib-7 was more resistant to the action of molecular oxygen compared to Desulfomicrobium sp. Rod-9. The activity of superoxide dismutase, $\mathrm{V}_{0}$ and $\mathrm{V}_{\text {max }}$ was significantly higher in the D. piger Vib- 7 cells than Desulfomicrobium sp. Rod-9. According to these data, Desulfomicrobium sp. Rod-9 strain can be more sensitive. Probably, this sensitivity makes impossible for survival of studied bacteria in environmental conditions where the effect of molecular oxygen is toxic. Therefore, the bacteria of Desulfomicrobium genus is less isolated from feces of humans and animals compared to the Desulfovibrio bacteria.

It is well known that sulfate-reducing bacteria are strict anaerobes, their growth is suppressed by low concentrations of $\mathrm{O}_{2}$ caused not only by generation of reactive oxygen species but also by its competition with $\mathrm{SO}_{4}^{2-}$ as an acceptor of electrons [9]. The results of our study are consistent to previous kinetic constants that characterize the enzymes activity of antioxidant systems of various microorganisms [8]. However, many sulfate reducers are aerotolerant. Moreover, in some Desulfovibrio (D. vulgaris and $D$. desulfuricans) $\mathrm{O}_{2}$ is reduced to water during respiration $[7,16]$. The Desulfovibrio strains generally exhibit $\mathrm{O}_{2}$ reduction rates comparable to those of aerobes, but these rates often decrease by increasing the $\mathrm{O}_{2}$ concentration and slow down after repeated oxygen additions $[4,5,6,11]$.

In summary, the highest activity of superoxide dismutase in cell-free extract of the intestinal strains D. piger and Desulfomicrobium sp. was measured for the first time. The maximal enzyme activity for both bacterial strains was determined at $+30{ }^{\circ} \mathrm{C}$. The optimum $\mathrm{pH} 8.0$ and $\mathrm{pH} 8.5$ for activity of the studied enzyme was measured in cell-free extracts of D. piger Vib-7 and Desulfomicrobium sp. Rod-9, respectively. The obtained data on optimal $\mathrm{pH}$ on activity of the enzyme is consistent to conditions of the human large intestine where range of $\mathrm{pH}$ is 8.0...9.0. Such conditions can provide the intensive growth of the bacterial strains, dissimilatory sulfate reduction and, respectively, accumulation of hydrogen sulfide in the gut. The superoxide dismutase activity, $\mathrm{V}_{0}$ and $\mathrm{V}_{\max }$ was higher in the D. piger Vib- 7 cells than Desulfomicrobium sp. Rod-9. These studies might help in predicting the 
development of diseases of the gastrointestinal tract, by providing further details on the etiology of bowel diseases which are very important for the clinical diagnosis of these disease types. Understanding the role of sulfate-reducing bacteria in colonic conditions would be enhanced by the ability to inhibit the number of the sulfatereducing bacteria and/or reduce the production of sulfide.

\title{
І.В. Кушкевич ${ }^{1}$, Г.Л. Антоняк ${ }^{2}$, Р.В. Фафула ${ }^{3}$
}

${ }^{1}$ Інститут біології тварин НААН України, вул. В. Стуса, 38, Львів, 79034, Україна

${ }^{2}$ Львівський національний університет імені Івана Франка, вул. Грушевського 4, 79005 Львів, Україна

3 Львівський національний медичний університет імені Данила Галицького, вул. Пекарська 69, 79010 Львів, Україна

\section{АКТИВНІСТЬ І КІНЕТИЧНІ ВЛАСТИВОСТІ \\ СУПЕРОКСИДДИСМУТАЗИ СУЛЬФАТВІДНОВЛЮВАЛЬНИХ \\ БАКTЕРIЙ DESULFOVIBRIO PIGER VIB-7 TA DESULFOMICROBIUM SP. ROD-9}

\begin{abstract}
Реферат
Метою роботи було дослідження активності супероксиддисмутази безклітинних екстрактів Desulfovibrio piger Vib-7 i Desulfomicrobium sp. Rod9, виділених з товстого кишечника людини, і проведення аналізу кінетичних властивостей ензиматичної реакції. Методи. Використано мікробіологічні, біохімічні, біофізичні методи досліджень і методи статистичної обробки результатів. Результати. Досліджено питому активність супероксиддисмутази сульфатвідновлювальних бактерій. Показано вплив різної температури, рН та концентрації субстрату на активність досліджуваного ензиму. На основі експериментальних даних, проведено аналіз кінетичних властивостей супероксиддисмутази досліджуваних бактеріальних штамів. Розраховано початкову (миттєву) швидкість реакиї $\left(V_{\theta}\right)$, максимальну швидкість ензиматичної реакиї $\left(V_{\text {max }}\right)$, і константи Міхаеліса $\left(K_{s}\right)$ реакиї супероксиддисмутази для обох итамів. Висновок. Кінетичні параметри реакиії супероксиддисмутази обох итамів бактерій статистично не відрізнялися. Отримані дані про вплив оптимуму рН (7,5-9,5) на активність ферменту узгоджуються зі значенням рН у товстому кишечнику людини. Ці умови забезпечують інтенсивний ріст бактеріальних итамів, прочес дисиміляційного відновлення сульфату $i$, відповідно, накопичення гідроген сульфіду у кимечнику.
\end{abstract}

Ключ в в сл в в : сульфатвідновлювальні бактерії, активність супероксиддисмутази, кінетичні властивості. 


\title{
И.В. Кушкевич ${ }^{1}$, Г.Л. Антоняк ${ }^{2}$, Р.В. Фафула ${ }^{3}$
}

${ }^{1}$ Институт биологии животных НААН Украины, ул. В. Стуса, 38, Львов, 79034, Украина

${ }^{2}$ Львовский национальный университет имени Ивана Франко, ул. Грушевского 4, 79005 Львов, Украина

${ }^{3}$ Львовский национальный медицинский университет имени Данила Галицкого, ул. Пекарская 69, 79010 Львов, Украина

\section{АКТИВНОСТЬ И КИНЕТИЧЕСКИЕ СВОЙСТВА СУПЕРОКСИДДИСМУТАЗЫ СУЛЬФАТВОССТАНАВЛИВАЮЩИХ DESULFOVIBRIO PIGER VIB-7 И DESULFOMICROBIUM SP. ROD-9}

\begin{abstract}
Реферат
Целью работы было исследовать активность супероксиддисмутазы бесклеточных экстрактов Desulfovibrio. piger Vib-7 и Desulfomicrobium sp. Rod-9, выделенных из толстого кишечника человека и провести анализ кинетических свойств энзиматической реакции. Методы. Использованы микробиологические, биохимические, биофизические методы исследований и методы статистической обработки результатов. Результаты. Исследована удельная активность супероксиддисмутазы сульфатвосстанавливающих бактерий. Показано влияние разной температуры, рН и концентрации субстрата на активность исследуемого фермента. На основе экспериментальных данных проведен анализ кинетических свойств супероксиддисмутазы исследуемых бактериальных итаммов. Рассчитана начальная (мгновенная) скорость реакции $\left(V_{0}\right)$, максимальная скорость энзиматической реакции $\left(V_{\text {max }}\right)$ и константа Михаэлиса $\left(K_{s}\right)$ реакции супероксиддисмутазы для обоих итаммов. Вывод. Кинетические параметры реакции супероксиддисмутазы обоих итаммов бактерий статистически не отличались. Полученнье даннье о влиянии оптимума $\mathrm{pH}(7,5-9,5)$ на активность фермента согласуются со значением рН в толстом кишечнике человека. Такие условия обеспечивают интенсивный рост бактериальных итаммов, процесс диссимиляционного восстановления сульфата и, соответственно, накопление гидроген сульфиду в кишечнике.
\end{abstract}

Ключев ве с слова: сульфатвосстанавливающие бактерии, активность супероксиддисмутазы, кинетические свойства.

\section{References}

1. Bailey N.T.J. Statistical Methods in Biology. Cambridge University Press. 1995. - $255 \mathrm{p}$.

2. Barton L.L., Hamilton W.A. Sulphate-Reducing Bacteria. Environmental and Engineered Systems. Cambridge: Cambridge University Pres. - 2010. - 553 p.

3. Beavchamp C., Fridovich I. Superoxide dismutase: improved assays and an assay apliciable to acrylamide gels // Anal. Biochem. - 1971 - - 44(1). - P. 276-287.

4. Brioukhanov A.L., Thauer R.K., Netrusov A.I. Catalase and Superoxide Dismutase in the Cells of Strictly Anaerobic Microorganisms // Microbiology. -2002. - 71(3).- P. 330-335. 
5. Brioukhanov A.L., Netrusov A.I. Catalase and Superoxide Dismutase: Distribution, Properties, and Physiological Role in Cells of Strict Anaerobes // Biochemistry. - 2004. - 69(9). - P. 949-962.

6. Dannenberg S., Kroder M., Dilling W., Cypionka H. Oxidation of $\mathrm{H}_{2}$, organic compounds and inorganic sulfur compounds coupled to reduction of $\mathrm{O}_{2}$ or nitrate by sulfate-reducing bacteria // Arch. Microbiol. - 1992. -158. - P. 93-99.

7. Fridovich I. Superoxide Radical and Superoxide Dismutases // Annu. Rev. Biochem. - 1995. - 64. - P. 97-112.

8. Gudelj M., Fruhwirth G.O., Paar A. et al. A catalase-peroxidase from a newly isolated thermoalkaliphilic Bacillus sp. with potential for the treatment of textile bleaching effluents // Extremophiles. - 2001. - 5.- P. 423-429.

9. Ito T., Nielsen J.L., Okabe S., Watanabe Y., Nielsen P.H. Phylogenetic identification and substrate uptake patterns of sulfatereducing bacteria inhabiting an oxic-anoxic sewer biofilm determined by combining microautoradiography and FISH // Appl. Environ. Microbiol. - 2002. - 68.- P. 356-364.

10. Keleti T. Basic Enzyme Kinetics. - Akademiai Kiado. - 1988. - 422 p.

11. Krekeler D., Teske A., and Cypionka H. Strategies of sulfate-reducing bacteria to escape oxygen stress in a cyanobacterial mat // FEMS Microbiol. Ecol. - 1998. 25(2).- P. 89-96.

12. Kushkevych I.V. Sulfate-reducing bacteria of the human intestine. II. The role in the diseases development // Sci. Int. J. Biological studies/Studia Biologica. 2012. - 6 (2).- P. 221-250. (in Ukrainian)

13. Kushkevych I.V. Identification of sulfate-reducing bacteria strains of human large intestine // Sci. Int. J. Biological studies/Studia Biologica. - 2013. - 7(3). P. $115-124$.

14. Kushkevych I.V., Bartoš M., Bartošová L. Sequence analysis of the $16 \mathrm{~S}$ rRNA gene of sulfate-reducing bacteria isolated from human intestine // Int. J. Curr. Microbiol. Appl. Sci. - 2014. - 3(2). - P. 239-248.

15. Lowry O.H., Rosebrough N.J., Farr A.L., Randall R.J. Protein determination with the Folin phenol reagent // J. Biol. Chem. - 1951. - 193. - P. 265-275.

16. Sies H. Strategies of antioxidant defense // Eur. J. Biochem. - 1993. - 215. P. 213-219. 